\title{
産業用多関節ロボットアームのトルク制限を考慮した 輪郭制御性能の限界とその実現法
}

\author{
中 村 政 俊*・青 木 重 人* \\ 後藤聡* 久 良 修 郭**
}

Upper Limit of Performance for Contour Control of Industrial Articulated Robot Arm with Torque

Constraints and Its Realization

Masatoshi NAKAmURA*, Shigeto AOKI*,

Satoru Gото* and Nobuhiro KYURA**

\begin{abstract}
Performance at high speed with high accuracy is required for contour control of industrial robot arms. Torque saturation exsiting in the industrial robot arms often causes deterioration of contour control performance. In this research, the following items of the contour control performance of industrial articulated robot arms under torque constraints is considered; 1 . derivation of a relationship among the torque, accuracy of the trajectories and operation speed, 2. clarification of the upper limit of the contour control performances of industrial articulated robot arms, 3. proposal of the contour control method which enables the best contour control performance under the torque constraints. The effectiveness of the proposed contour control method was assured by experimental results of an actual industrial robot arm.
\end{abstract}

Key Words: industrial articulated robot arm, contour control performance, torque saturation, trajectory generation, modified taught data method

\section{1. まえがき}

組立, 切削, 溶接, 塗装作業などに利用される産業用ロボッ トアームに関して, その作業の多様化に伴って, 要求される 動作に忠実に追従する高速高精度な輪郭制御性能が必要とさ れている。このような要求を実現する上で問題となるのは, パワーアンプの電流制限やロボットアームのアクチュエータ であるモー夕の仕様などからくるトルク制限や， ロボット アームを構成する各リンクの特性の相違などによる輪郭制 御性能の低下である。特に追従軌跡におけるオーバーシュー トは，製品の精度に直接影響を与えるため極力避ける必要が ある。

アクチュエータ飽和問題については数多くの研究がなされ ているが, これらの多く1) 4) はフィードバックタイプの制 御器でありハードウェアの変更を伴う，産業界において, 現

* 佐賀大学大学院工学系研究科 佐賀市本庄町 1

** 近畿大学九州工学部 飯塚市柏の森 11-6

* Graduate school of Science and Engineering, Saga University, Saga

** Faculty of Engineerring in Kyushu, Kinki University, Iizuka

(Received April 3, 1998)

(Revised October 19, 1998)
状の型式のロボットで輪郭制御を行う場合には，ハードウェ アの変更は極力避け, 制御性能の限界を達成したいという要 求がある。一方我々は，この産業界における実現性を念頭に おいてロボットアームの輪郭制御に対するフィードフォワー ド，すなわち，ハードウェアの変更の必要がない手法を提案 してきた5) 7). また，その他の研究でロボットアームの輪 郭制御のための動的軌道生成法も提案されている ${ }^{8)}$. しかし ながら，ロボットアームのトルク制限下における輪郭制御性 能の限界や, その限界性能の実現法の研究成果は著者の知り うる限りでは未だ存在しない.

本論文では, 多関節ロボットアームの発生トルク, 輪郭制 御精度, 動作速度の 3 者の関係を理論的に導き, トルク制限 下に㧍ける輪郭制御性能の限界を明らかにする。ささらに, ト ルク制限を考慮した軌道生成と教示信号修正法 ${ }^{9)}$ に基づく多 関節ロボットアームの輪郭制御性能限界の実現法を提案する。 提案法は，トルク制限による輪郭制御性能劣化を避けるため にトルク制限にかからない範囲でロボットアームを動作させ るものであり，トルク制限が生じない軌道を作業座標系で生 成し，関節座標系でロボットアームのダイナミクスの遅れを 補償するものである，本方法では，産業用ロボットアームの 設計仕様から定まるトルクの制限值がわかると，ロボットが 達成できる輪郭制御性能の限界值 (精度, 動作速度) がわか 
り, 逆に, 輪郭制御性能の仕様が与えられれば, それを実現 するのに必要なトルク (パワーアンプ, モータサイズ) を決定 することができる.フィードバックタイプの制御器では, 口 ボットアームのハードウェアの変更を必要とするが, 本方法 は，ロボットアームのハードウェア変更を必要としないため 産業界で有効に利用でき，この手法を用いることにより，指 定された作業精度を満足させ, 輪郭制御性能の限界を達成す ることが可能となる。

\section{2. 産業界におけるトルク制限問題}

産業用ロボットアームの高精度輪郭制御を行うときに生じ る制御性能の劣化の原因として, 最も大きな問題としてはト ルク制限がある。トルク制限は, サーボコントローラとモー 夕の特性によって引き起こされる現象で，ロボットアームに 大きなトルク指令を与えても実際にはそれに応じたトルクが 発生しない現象のことを言う.

産業用ロボットアームのトルク制限の原因として, 以下の 3 点があげられる。

（1）最大許容電流值によって，トルク電流が制限される.

（2）モータへ印加する端子電圧とモー夕の逆起電力との 差の違いによって, 加減トルクに使用できる電圧值が変化 する。

（3）制御系の操作量の飽和, ·すわち, 速度制御部と電 流制御部のクリップによって飽和が生じる以前に制限がか けられている。

（1）に関しては, 産業用ロボットアームでは, 定格トルクの 3〜5 倍程度が出力できるモータへ最大許容電流值以上の電 流が流れようとする場合には, サーボ系はアラームを鳴らし， 電源遮断等の方策を取り, サーボ系を停止する。この定格の 3〜 5 倍程度というのは, 瞬時にモータが出力できるトルク で，これはパワーアンプの電流制限によって決定される。ま た定格トルク相当以上の電流が一定時間 (約 $1[\mathrm{~s}]$ ) 以上流れる ときでも, サーボを停止する。これらは，過電流によりモー 夕が焼きつくことや熱による絶縁破損を避けるための対策で ある。

（2）に関しては, 産業用ロボットアームでは, 逆起電力 の補償が行われていて, 高速回転時においても定格卜ルクの 3～5 倍程度の出力ができるように電流を流すことができる． この逆起電力補償とは, モー夕の最大回転数における逆起電 力に対して PWM アンプで印加するモー夕の端子電圧を十分 大きくとることにより，モータへの電流を定格トルクの3〜 5 倍程度まで流す方法である。

（3）に関しては, 実際の装置の安全性を考慮して, 飽和 にかかる以前に, サーボコントローラ内の速度制御部と電流 制御部でクリップ (制限) がかけられている. 速度制御部のク リップは速度の変化量, すなわち加速度がある值を超えない ようにしているものであり, 電流制御部のクリップは, 電流 がある值を超えないようにしているものと電流の変化量があ る值を超えないようにしているものの両者が存在する。これ
らのクリップにより, 産業用ロボットアームのトルク出力は 制約を受けることになる。このトルク制限により，高速時に おいてロボットアームのダイナミクスが非線形となるため, 輪郭制御性能が著しく劣化する。

\section{3. 産業用ロボットアームの制御系および数式モデル}

\section{1 ロボットアームの制御系}

本研究において対象とする多関節ロボットアームは Fig. 1 に示すように直線で表す 2 つの剛体が○で表す関節でつな がっていて，先端が平面上を自由に動くようになっている。 図中の $(\alpha, \beta)$ は関節座標系の関節角, $(x, y)$ は作業座標系に おけるアームの先端の位置, $l_{1}, l_{2}$ はそれぞれのリンクの長 さを表す。ここで, 作業座標系と関節座標系との関係を明確 にするために, 関節座標 $(\alpha, \beta)$ から作業座標 $(x, y)$ への変換 (キネマティクス) と, 作業座標 $(x, y)$ から関節座標 $(\alpha, \beta)$ へ の変換 (逆キネマティクス) を示す. キネマティクスは

$$
\begin{aligned}
& x=l_{1} \cos \alpha+l_{2} \cos (\alpha+\beta) \\
& y=l_{1} \sin \alpha+l_{2} \sin (\alpha+\beta)
\end{aligned}
$$

であり, 逆キネマティクスは

$$
\begin{aligned}
& \alpha=\sin ^{-1}\left(\frac{y}{\sqrt{x^{2}+y^{2}}}\right)-\sin ^{-1}\left(\frac{l_{2} \sin \beta}{\sqrt{x^{2}+y^{2}}}\right)(3) \\
& \beta= \pm \cos ^{-1}\left(\frac{x^{2}+y^{2}-l_{1}^{2}-l_{2}^{2}}{2 l_{1} l_{2}}\right)
\end{aligned}
$$

で与えられる。ここで，(4) 式の符号は，作業座標が1点を表 すのに，関節座標では 2 通りの可能性があること示している.

産業用ロボットアームで一般曲線の輪郭制御を行う際には 折れ線近似が用いられる。まず作業座標系における目標軌道 を微小区間に分割して折れ線近似する．次にその分割点に対 応する関節角を各軸に対して計算し，各軸の関節角が分割さ れた関節座標系における目標関節角まで一定速度で動くよう にサーボモータの回転角の制御を行う. 各軸のサーボモー夕 は回転角の移動量だけ回転し、アームの機構による座標変換 でアームの先端が目標軌道に沿って動く.

ロボットアームの輪郭制御性能に対する要求事項は, 指定 の速度で目標軌跡にできるだけ正確に追従させることである.

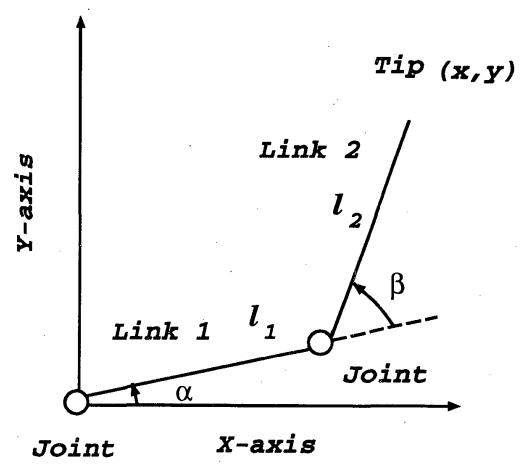

Fig. 1 Structure of an articulated robot arm 


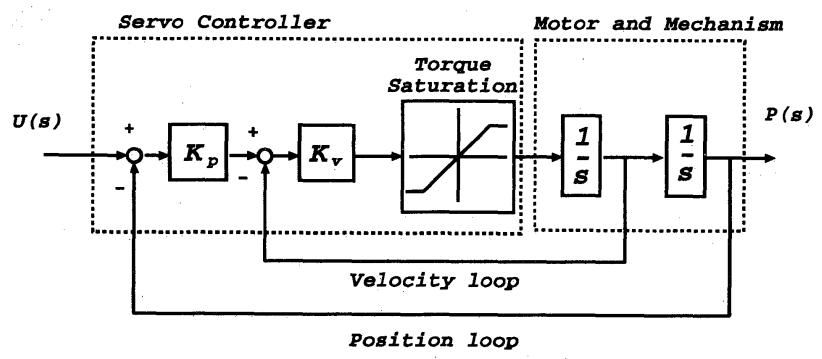

Fig. 2 Block diagram of the mechatoronic system

ここで，軌跡とは時間の概念を取り去った空間的な図形を意 味し，軌跡に対して軌道は時間の概念を含めた時間的推移を 意味する。折れ線近似された目標軌跡の角の部分においては 大きなトルクが必要となり, トルク制限が起きると追従軌跡 にオーバーシュートが生じ, 高精度な輪郭制御性能が得られ ない，そのため現状では，ロボットアームの輪郭制御はトル ク制限が生じない速度領域で動作させているが, 一方では動 作の高速化への要求がある.

\section{2 ロボットアームの数式モデル}

産業用の多関節ロボットや工作機械では, 動作する各軸の サーボモータが独立に制御されている。実際には, 機構部の 構成によって軸の干渉や摩擦が異なるが，各軸の干渉を減ら すように機構上の工夫がなされており，多くの産業用多関節 ロボットでは平行リンク機構を用いて非干渉化がなされてい るため, 通常の動作条件では，軸干渉は無視できる。また， 速度制御器はPI 制御器が使われており,トルク外乱は速度 PIのI動作で補償されている. そのため非線形要素は無視で き，ロボットアームの関節座標系での各軸のダイナミクスは アクチュエータであるサーボモータとその制御器をあわせて 各軸独立に

$$
\frac{d^{2} p(t)}{d t^{2}}=\operatorname{sat}\left(K_{v}\left(K_{p}(u(t)-p(t))-\frac{d p(t)}{d t}\right)\right)
$$

と表される (Fig. 2 参照). ここで, $\operatorname{sat}(z)$ はトルク制限を 表し

$$
\operatorname{sat}(z)= \begin{cases}A_{\max } & \left(A_{\max }<z\right) \\ z & \left(-A_{\max } \leq z \leq A_{\max }\right) \\ -A_{\max } & \left(z<-A_{\max }\right)\end{cases}
$$

である.（5）式の $u(t)$ は角度入力, $p(t)$ は角度出力, $K_{p}$ は位 置ループゲイン， $K_{v}$ は速度ループゲイン, $(6)$ 式の $A_{\max }$ は 各軸の最大角加速度であり, $A_{\max }$ にモー夕軸換算慣性モー メントをかけたものがトルク制限である。

トルク制限が生じない領域においては，ロボットアームの ダイナミクスは

$$
P(s)=\frac{K_{p} K_{v}}{s^{2}+K_{v} s+K_{p} K_{v}} U(s)
$$

で表される ${ }^{10)}$. 本研究では, ロボットアームのダイナミクス が（7）式で表されるような領域で高精度輪郭制御を実現す ることを目指す。

\section{4.トルク制限下における輪郭制御性能と高精度 輪郭制御法}

\section{1 トルク制限下における輪郭制御性能}

一般に産業界で用いられているサーボコントローラでは, サーボ系への指令デー夕は，指令時間間隔ごとに与えられて おり，一般曲線を作業座標系で指令時間間隔ごとにデー夕を 分割し，この分割した点と点を結んだ直線で表現する．指令 時間間隔は一般曲線を折れ線で近似しても軌跡誤差を無視で きるように細かく設定している，従って，産業界では折れ線 近似した目標軌道に正確に追従させることを目指すことによ り，一般曲線の輪郭制御を実現している。

Fig. 3 に示されるような折れ線で表される 2 直線からなる 目標軌跡に対して,トルク制限下における輪郭制御性能を導 出する。輪郭制御において目標速度 $v$ はできるだけ一定であ ることが要求されるため, 2 直線の角の部分において，それ を実現させるのに必要な加速度が無限大となり, 折れ線近似 をそのままロボットアームで描かせることはできない. 本研 究では, Fig. 3 に示すように, 目標軌跡の角の部分を円で近 似を行う.この円の半径を $r$ とし, 円の生成軌跡と折れ線目 標軌跡の誤差の最大值を作業精度 $\epsilon$ と定義する. 円の半径 $r$ と 作業精度 $\epsilon$ の関係は Fig. 3 の幾何学的関係から

$$
\cos \left(\frac{\theta_{2}-\theta_{1}}{2}\right)=\frac{r}{r+\epsilon}
$$

となり，（8）式を $r$ について解くと，作業精度 $\epsilon$ を満足する円 の半径 $r$ は

$$
r=\frac{\epsilon \cos \left(\left(\theta_{2}-\theta_{1}\right) / 2\right)}{1-\cos \left(\left(\theta_{2}-\theta_{1}\right) / 2\right)}
$$

によって計算される。、ロボットアームが出し得る作業座標 系における最大加速度 $a_{\text {max }}$ は装置に依存する．また，Fig. 3 に示されるように，目標軌跡において軌跡角度 $\theta_{1}, \theta_{2}$ は与え られている。輪郭制御の作業内容によって, 目標速度 $v$ と作 業を行うに最低限必要な最小速度 $v_{\min }$ と作業精度 $\epsilon$ 与字えら れる．以下に，制御性能の指標である最小速度 $v_{m i n}$ と作業精 度 $\epsilon$ とトルクに関係する最大加速度 $a_{\max }$ に関する基本的な関 係式を導く。

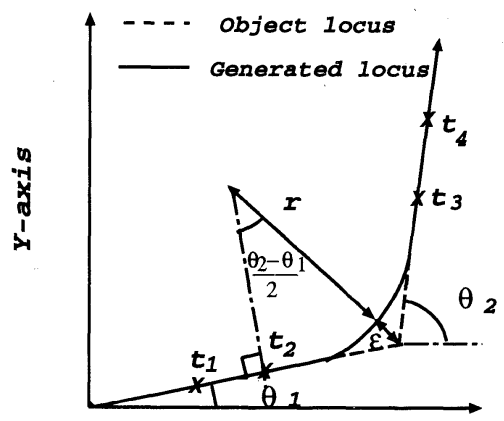

$x$-axis

Fig. 3 Trajectory generation for the objective locus consists of two lines and one corner 


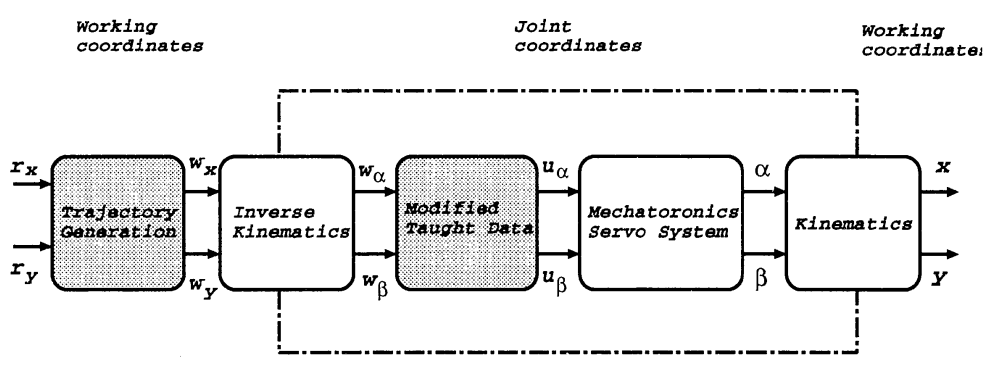

Fig. 4 Structure of the contour control of the mechatronic system

4.1.1 最小速度 $v_{\min }$ が与えられた時の作業精度 $\epsilon$ の限界值 円軌道の加速度は $a=r \omega^{2}$ で表される．ここで, $\omega=v / r$ であるので，これを代入すると $r=v^{2} / a$ となる，従って，最 小速度 $v_{\min }$ と最大加速度 $a_{\max }$ で描ける円の半径の範囲は

$$
r \geq \frac{v_{\min }^{2}}{a_{\max }}
$$

で表される. 半径 $r$ と作業精度 $\epsilon$ との関係は（9）式で表され， にについて解くことにより

$$
\epsilon=\left(\frac{1}{\cos \left(\left(\theta_{2}-\theta_{1}\right) / 2\right)}-1\right) r
$$

となる。これと $(10)$ 式の関係より, 最小速度 $v_{m i n}$ が与えら れた時の作業精度 $\epsilon$ の範囲は

$$
\epsilon \geq\left(\frac{1}{\cos \left(\left(\theta_{2}-\theta_{1}\right) / 2\right)}-1\right) \frac{v_{\min }^{2}}{a_{\max }}
$$

となる。

4.1.2 作業精度 $\epsilon$ 与゙えられた時の最小速度 $v_{\text {min }}$ の限界值 作業精度 $\epsilon$ 与方られた時の半径 $r$ は (9) 式で表される。 こ の半径 $r$ と最大加速度 $a_{\max }$ で描ける最小速度 $v_{\min }$ は, (10) 式より $v_{\text {min }} \leq \sqrt{a_{\max } r}$ で表される。この式の $r に(9)$ 式を

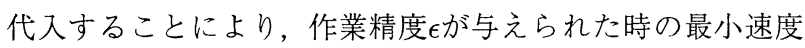
$v_{\min }$ の範囲は

$$
v_{\text {min }} \leq \sqrt{\frac{a_{\max } \epsilon \cos \left(\left(\theta_{2}-\theta_{1}\right) / 2\right)}{1-\cos \left(\left(\theta_{2}-\theta_{1}\right) / 2\right)}}
$$

で表される。

\section{2 トルク制限を考慮した輪郭制御}

産業用ロボットアームの輪郭制御では，トルク制限が生じ ない領域で動作させている，そのため，ロボットアームの軌 道はトルク制限領域にかからないように決定する必要がある。

Fig. 4 にロボットアームの輪郭制御構成を示す. トルク制限 を考慮した輪郭制御法は大きく 2 つの部分に分けられる。 1 つはトルク制限が生じないような軌道を作業座標系において 生成する部分と，もう1つはロボットアームのダイナミクス の遅れを補償する部分である。

生成軌道 $\left(w_{x}(t), w_{y}(t)\right)$ は，まず，Fig. 4 に示されるよう に，ロボットアームがトルク制限にかからずに，かつ目標軌 跡 $\left(r_{x}, r_{y}\right)$ と生成軌跡 $\left(w_{x}, w_{y}\right)$ との誤差が作業精度 $\epsilon$ を満足 するように軌跡を生成する. 生成軌跡 $\left(w_{x}, w_{y}\right)$ に与える接 線速度は，トルク制限領域にかからない範囲で，できる限り 目標速度 vに近づける。
生成軌道 $\left(w_{x}(t), w_{y}(t)\right)$ を入力軌道 $\left(u_{x}(t), u_{y}(t)\right)$ に直接 用いると，ロボットアームのダイナミクスの遅れから追従軌 跡 $(x, y)$ が生成軌跡 $\left(w_{x}, w_{y}\right)$ から劣化する。そこで教示信 号修正法 ${ }^{9)}$ 関節座標系に組み込むことによりダイナミクス の遅れを補償し, 生成軌跡 $\left(w_{x}, w_{y}\right)$ と追従軌跡 $(x, y)$ を指 定された作業精度 $\epsilon$ 内で一致させうる。

\section{3 トルク制限を考慮した軌道生成}

Fig. 3 に示されるような 2 直線からなる目標軌跡 $\left(r_{x}, r_{y}\right)$ に対して時間概念を入れた軌道を生成する場合，ロボット アームのトルク制約条件下での軌道生成法を以下に示す.

（1）目標軌跡 $\left(r_{x}, r_{y}\right)$ に角が存在する場合には，作業精 度 $\epsilon$ を満足するように円で角を近似する。

（2）生成軌跡 $\left(w_{x}, w_{y}\right)$ に含まれる円の半径を $r$ とおき, トルク制約条件を満たす最小半径 $r_{\text {min }}\left(=v^{2} / a_{\max }\right)$ を 最大加速度 $a_{\max }$ と接線速度 $v$ から計算する. 多関節口 ボットアームでは目標軌跡 $\left(r_{x}, r_{y}\right)$ が与えられると, 指 令時間間隔ごとの目標軌跡 $\left(r_{x i}, r_{y i}\right)$ は $(1),(2)$ 式より

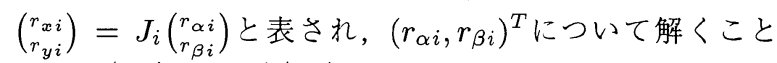
により $\left(\begin{array}{c}r_{\alpha i} \\ r_{\beta i}\end{array}\right)=J_{i}^{-1}\left(\begin{array}{c}r_{x i} \\ r_{y i}\end{array}\right)$ となる.ここで $\left(r_{\alpha i}, r_{\beta i}\right)$ は目標 軌跡 $\left(r_{x i}, r_{y i}\right)$ に対応する関節角である。これより関節座 標系の最大角加速度と作業座標系の最大加速度の関係は, $\left(\begin{array}{l}d^{2} r_{\alpha i} / d t^{2} \\ d^{2} r_{\beta i} / d t^{2}\end{array}\right)=J_{i}^{-1}\left(\begin{array}{l}d^{2} r_{x_{i}} / d t^{2} \\ d^{2} r_{y i} / d t^{2}\end{array}\right)$ となり, 関節座標系の最大角 加速度は $A_{\max }=\max \left(d^{2} r_{\alpha i} / d t^{2}, d^{2} r_{\beta i} / d t^{2}\right)^{T}$ と表され るので, 関節座標系の角加速度が最大角加速度 $A_{\max }$ 以下 になるように作業座標系における最大加速度 $a_{\max }$ と設定 する。ここで，Jiはヤコビアンである.

(a) $r \geq r_{m i n}$ の場合：生成軌道 $\left(w_{x}(t), w_{y}(t)\right)$ は接線 速度が目標接線速度 $v$ となるように計算する.

( b ) $r<r_{\min }$ の場合: 以下の手順で軌道を生成する.

I. $t_{1}$ から $t_{2}$ までの区間で接線速度を $v$ から $v_{\min }($ 半 径 $r$ の円の加速度が $a_{\max }$ となるときの接線速度 $\left.v_{\min }=\sqrt{a_{\max } r}\right)$ まで最大減速度一 $a_{\max }$ で減速する.

II. $t_{2}$ から $t_{3}$ までの区間で軌跡は円を描く.

III. $t_{3}$ から $t_{4}$ の区間で接線速度が $v_{m i n}$ から $v$ になる まで最大加速度 $a_{\max }$ で加速する。

（3）目標軌跡の始点と終点においては, 最大加速度 $a_{\max }$ で加減速を行う.

以上述べた手順によって, 生成軌道 $\left(w_{x}(t), w_{y}(t)\right)$ は, トル ク制限にかからず, 生成軌跡 $\left(w_{x}, w_{y}\right)$ は目標軌跡 $\left(r_{x}, r_{y}\right)$ に 


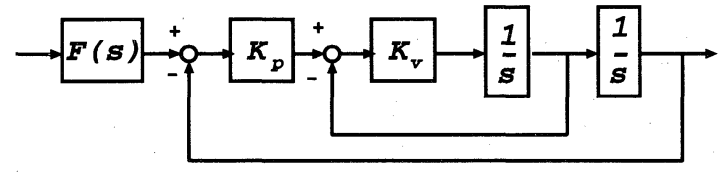

Fig. 5 Modified taught data method in the joint coordinates

作業精度 $\epsilon$ 内で一致させることができる.（2）（b）の場合の生 成軌道は

$$
\begin{aligned}
& w_{x}(t)= \\
& \left\{\begin{array}{rr}
v t \cos \theta_{1} & \left(t \leq t_{1}\right) \\
w_{x}\left(t_{1}\right)+\left(v\left(t-t_{1}\right)-a_{\max }\left(t-t_{1}\right)^{2} / 2\right) \cos \theta_{1} \\
\left(t_{1}<t \leq t_{2}\right) \\
w_{x}\left(t_{2}\right)+r\left(\sin \left(\theta_{1}+v_{\min }\left(t-t_{2}\right) / r\right)-\sin \theta_{1}\right) \\
\left(t_{2}<t \leq t_{3}\right) \\
w_{x}\left(t_{3}\right)+\left(v\left(t-t_{3}\right)+a_{m a x}\left(t-t_{3}\right)^{2} / 2\right) \cos \theta_{2} \\
\\
\left.w_{x}\left(t_{4}\right)+v t \cos \theta_{2}<t \leq t_{4}\right) \\
\left(t_{4}<t\right)
\end{array}\right.
\end{aligned}
$$

$$
\begin{aligned}
& w_{y}(t)= \\
& \left\{\begin{array}{rr}
v t \sin \theta_{1} & \left(t \leq t_{1}\right) \\
w_{y}\left(t_{1}\right)+\left(v\left(t-t_{1}\right)-a_{\max }\left(t-t_{1}\right)^{2} / 2\right) \sin \theta_{1} \\
\left(t_{1}<t \leq t_{2}\right) \\
w_{y}\left(t_{2}\right)+r\left(\cos \theta_{1}-\cos \left(\theta_{1}+v_{\min }\left(t-t_{2}\right) / r\right)\right) \\
\left(t_{2}<t \leq t_{3}\right) \\
w_{y}\left(t_{3}\right)+\left(v\left(t-t_{3}\right)+a_{\max }\left(t-t_{3}\right)^{2} / 2\right) \sin \theta_{2} \\
\left(t_{3}<t \leq t_{4}\right) \\
w_{y}\left(t_{4}\right)+v t \sin \theta_{2} \\
\left(t_{4}<t\right)
\end{array}\right.
\end{aligned}
$$

のように導出される。ここで, 減速と加速の時間間隔は $t_{4}-t_{3}=t_{2}-t_{1}=\left(v-v_{\min }\right) / a_{\max }$ であり, 円を描く時間 は $t_{3}-t_{2}=r\left(\theta_{2}-\theta_{1}\right) / v_{\text {min }}$ である.この方法は, 条件 $(2)$ (b) $r<r_{\min }$ の場合に, 急激な速度変化を防ぐため必要最 低限の速度低減を行い，円を描くため制御時間が僅かである が長くなる。しかし, 角の部分での追従軌跡 $(x, y)$ はトルク 制約条件を满足し, 生成軌跡 $\left(w_{x}, w_{y}\right)$ は目標軌跡 $\left(r_{x}, r_{y}\right)$ に 作業精度 $\epsilon$ 内で一致するため高精度な輪郭制御が行える。

\section{4 関節座標での教示信号修正}

トルク制限を考慮した輪郭制御法では, トルク制限が生 じない領域でロボットアームを動かすため, ダイナミクスは Fig. 2 から飽和特性を除いた線形 2 次系で表される. 修正要 素とあわせたロボットアームの各軸の制御系は, Fig. 5 の ように表せる。教示信号修正法は, 目標軌道を修正要素に よって修正した教示信号をロボットアームの入力として用い ることによって, 制御対象を目標軌道に追従させる方法であ $ろ^{9)}$. 生成軌道を入力軌道に直接用いると, ロボットアーム のダイナミクスの遅れにより追従軌跡が生成軌道から劣化す る. そのため, 関節座標系において修正を施すことによって,
ロボットアームのダイナミクスの遅れを補償する。修正は 1 次系モデルに基づくものと 2 次系モデルに基づくものの両方 に対して設計することが可能であるが，本研究では構造が簡 単な 1 次系モデルに基づく修正を用いた。修正要素 $F(s)$ は レギュレータ理論に基づいて設計し，各軸それぞれ

$$
F(s)=-\frac{\gamma\left(s+K_{p}\right)}{K_{p}(s-\gamma)}
$$

と表される，ここで， $\gamma$ はレギュレータの極である.

4.5 トルク制限を考慮した輪郭制御のアルゴリズム トルク制限を考慮した輪郭制御法全体の手順を以下に示す.

(1) 目標軌道 $\left(r_{x i}(t), r_{y i}(t)\right)$ から 4.3 節の手順に従って (13)，(14）式を用いて軌道を作成する.

（2）（3），(4）式を用いて作業座標系から関節座標系へ の座標変換を行う.

（3）関節座標系において 4.4節で示した教示信号修正法 を適用し，(15）式を用いてダイナミクスの遅れを補償する。

（4）、ロボットアームにダイナミクスの遅れを補償した生 成軌道を入力し, 追従軌跡を得る.

（5）（1），(2）式を用いて関節座標系から作業座標系へ の座標変換を行い，輪郭制御性能の評価を行う。

本論文では記述を簡単にするため, 2 軸のロボットアームで の 2 次元の作業座標系における輪郭制御について考察した が, 多軸のロボットアームの場合で 3 次元空間を動作する場 合においても，作業座標系で折れ線近似を行った目標軌道に おける 2 直線について考えると，この 2 直線は一つの平面上 にあるので 2 次元空間での方法と全く同じ手順を踏んで拡張 できる。

\section{5. トルク制限を考慮した輪郭制御の検証}

\section{1 仮想トルク制限発生法}

提案したトルク制限を考慮した輪郭制御法を多関節ロボッ トアーム PERFORMER-MK3S((株) 八幡電機精工製) に適 用した. PERFORMER-MK3S は 5 自由度の多関節ロボッ トアームで 5 つの軸をもつが，そのうち 2 つの軸を用いて 実験を行った．各関節のサーボコントローラは, 速度と電 流制御を行うサーボコントローラに接続され, サーボモー 夕は，位置制御を行う計算機に接続されている，各軸には， $\mathrm{AC}$ サーボモー夕(定格速度 $3000[\mathrm{rpm}]$ ) が用いられ, 減速器 を介してアームを駆動する，装置の条件は，位置ループゲ イン $K_{p}=25[1 / \mathrm{s}]$, 速度ループゲイン $K_{v}=150[1 / \mathrm{s}]$, 最 大角加速度 $A_{\max }=11.0\left[\mathrm{rad} / \mathrm{s}^{2}\right]$, サンプリング時間間隔 $\Delta t=6[\mathrm{~ms}]^{11)}$, アームの長さ $l_{1}=0.25[\mathrm{~m}], l_{2}=0.215[\mathrm{~m}]$, 各軸の減速比 $n_{1}=160, n_{2}=161$ である. 実験方法は, 位 置入力とモー夕の位置出力の差に位置ループゲイン $K_{p}$ を乗 じた值を速度入力として D/A コンバータを介してモータに 与えている。

実験で用いた PERFORMER-MK3S は大きなトルクを出 し得るが，提案した方法の有用性を確認するために，この装 置に仮想的にトルク制限をかけることを試みた。この方法は， 

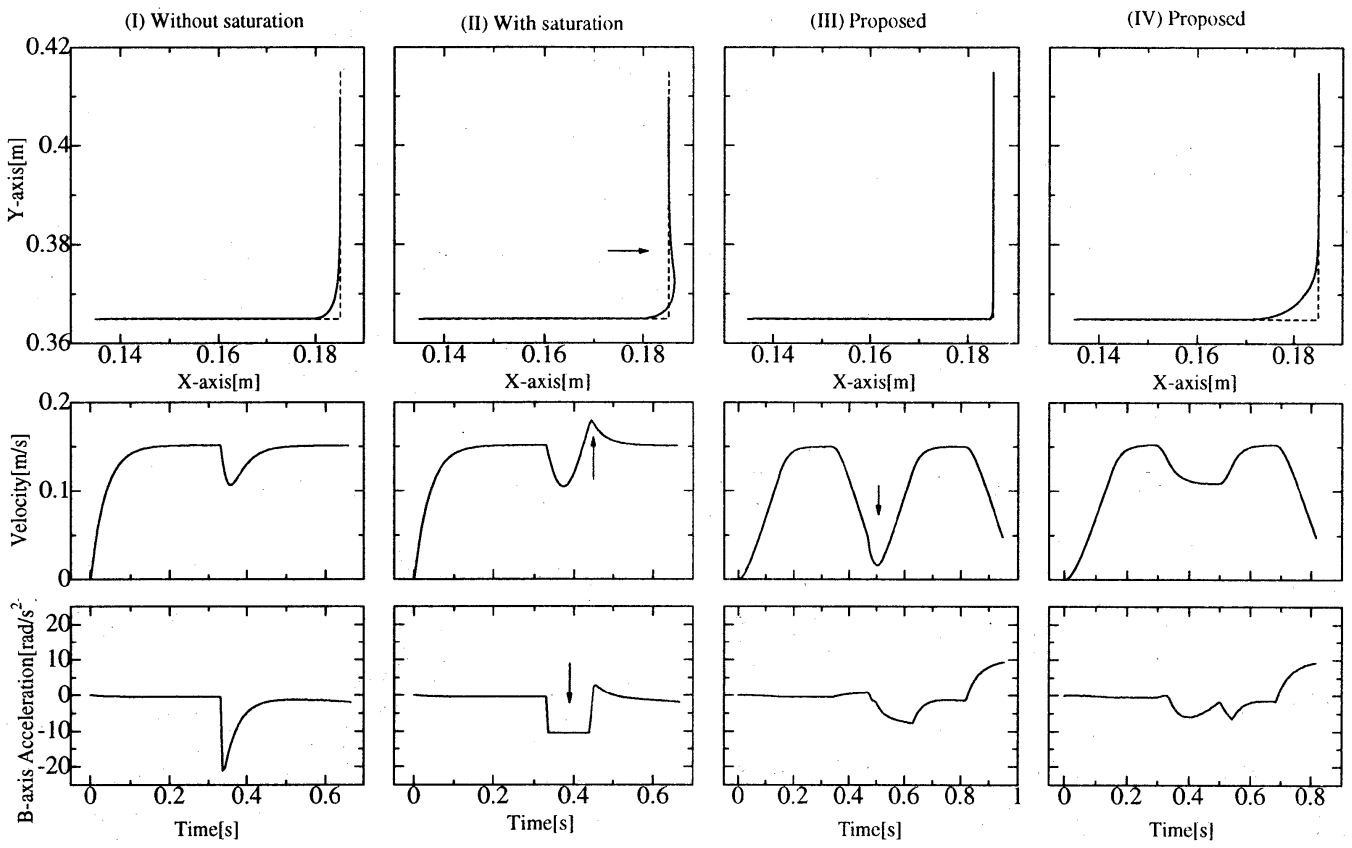

Fig. 6 Simulation results (I) Without saturation (II) With saturation (III)(IV) Proposed method
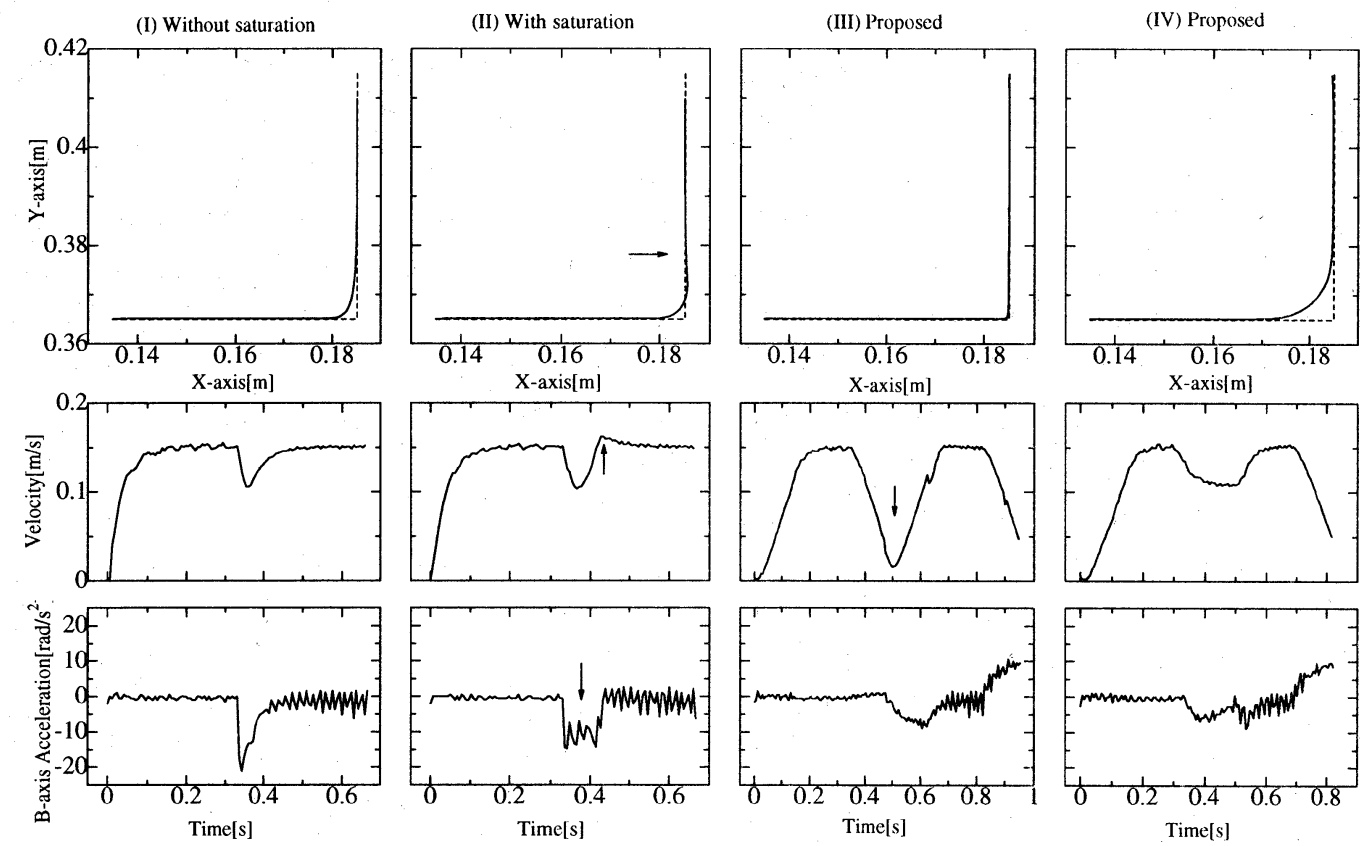

Fig. 7 Experiment results (I) Without saturation (II) With saturation (III)(IV) Proposed method

速度入力に注目し, 速度入力 $v_{i}$ と速度出力 $v_{f}$ の差に速度ルー プゲイン $K_{v}$ を乗じた実測角加速度出力が

$$
\left|K_{v}\left(v_{i}-v_{f}\right)\right|>A_{\max }
$$

を満たすならば速度入力 $v_{i}$ を

$$
v_{i}=\left|\frac{A_{\max }}{K_{v}}\right|+v_{f}
$$

のように変更し，角加速度が $A_{\max }$ 以上とならないようにす

るものである。トルク制限は機構に依存し機種ごとによって
特性が変化するが，この方法を用いることにより様々なトル ク特性をもった装置に関する実験が一つの装置で表現できる。

\section{2 シミュレーションおよび実験結果}

Fig. 6, Fig. 7 に 3 つの手法に対する軌跡, 合成速度およ び飽和がある B 軸の加速度のシミュレーションおよび実験結 果を示す.

手法 (I) として従来法 (目標軌道をそのまま口ボットアー ムの入力として用いる方法), 手法 (II) として仮想トルク制 

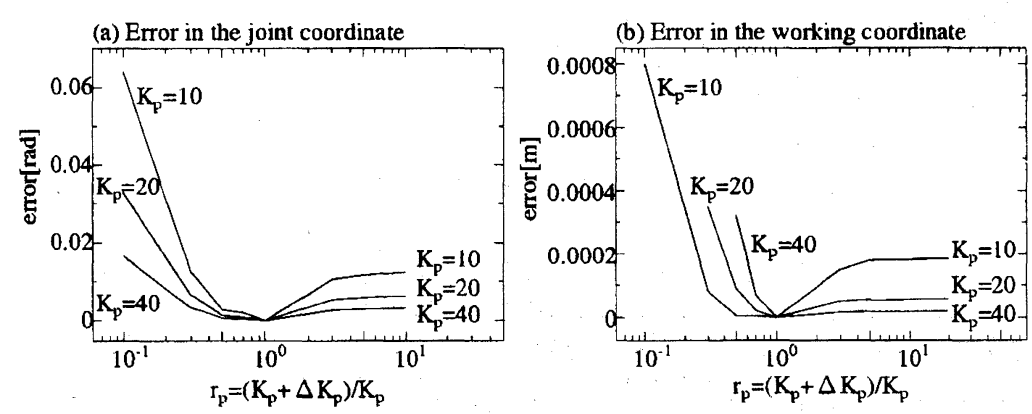

Fig. 8 Rationship between the modelling error ratio and the position error

限発生法でトルク制限をかけた状態における従来法, 手法 (III) として軌道生成と教示信号修正法をあわせた提案法を採 用した.シミュレーションおよび実験条件としては，作業精 度 $\epsilon=1.0 \times 10^{-4}[\mathrm{~m}]$, レギュレータの極 $\gamma=-30$, 指定され た接線速度 $v=0.15[\mathrm{~m} / \mathrm{s}]$, 最小速度 $v_{\min }=0.0155[\mathrm{~m} / \mathrm{s}]$, 目標軌跡は $(0.135,0.365) \sim(0.185,0.365) \sim(0.185,0.415)$ の 直交する長さ $0.05[\mathrm{~m}]$ の 2 直線とし， 4.3 節で述べた関節座 標系における最大角加速度 $A_{\max }$ と目標軌跡加ら与えられる 作業座標系における最大加速度は $a_{\max }=1.0\left[\mathrm{~m} / \mathrm{s}^{2}\right]$ と計算 された。

手法 (I) の追従軌跡ではシミュレーションおよび実験結果 において角の部分で，丸みをおびた軌跡の劣化が見られる. この劣化の原因は, ロボットアームのダイナミクスの遅れで あり，トルク制限にかかっているのではないのが加速度の結 果からもわかる。一方, 手法 (II) のシミュレーションおよび 実験結果において, 各軸の加速度の結果を見ると B 軸の矢印 の部分の $0.33[\mathrm{~s}] \sim 0.44[\mathrm{~s}]$ にかけて制限にかかっているのが わかる．また，シミュレーションと実験結果の間には実験誤 差が少し見られるが，同じ傾向として追従軌跡の矢印部分で は, シミュレーションで $1.35[\mathrm{~mm}]$, 実験で $0.74[\mathrm{~mm}]$, 合成 速度の矢印部分では, シミュレーションで $0.3[\mathrm{~m} / \mathrm{s}]$, 実験で $0.12[\mathrm{~m} / \mathrm{s}]$ のオーバーシュートが見られる.オーバーシュー 卜は, 加工精度に直接影響を与えるため極力避けなければな らない. 手法 (III) のシミュレーションおよび実験結果を見 ると追従軌跡の結果ではオーバーシュートがなく，合成速度 を見ると, 矢印の角の部分において必要最低限の速度低減を 図っているため, 手法 (I)(II) と比べて時間がかかっている が，ロボットアームのダイナミクスを補償し，トルク制限に かかっていないのがわかる。 また提案法 (III) では最小速度 $v_{m i n}=0.015[\mathrm{~m} / \mathrm{s}]$ の条件も満足していることがわかる.

先の結果は, 角でのトルク制限にかかるのを避け, 軌跡を 重視する条件で速度を目標速度の $10 \%$ 程度まで減速した結 果について示した，産業界では，レーザカッティング等の作 業の際に角での速度を落としすぎるとレーザの印加電流が下 がりすぎ，逆に速度を上げる時に電流を上げる時間がかかり すぎ応答が間に合わなくなり輪郭制御の精度が低下すると いう場合がある．そのときの速度が目標速度の $70 \%$ 程度で
あれば印加電流の応答の遅れは問題とならない. そこで, 目 標速度の $70 \%$ \%では下げられる条件の下で 4.1 節で述べた 関係を用いて作業精度を計算し，シミュレーションおよび実 験を行った結果を Fig. 6 と Fig. 7 の (IV) に示す. (11) 式よ り得られた作業精度の条件は， $\epsilon \geq 0.004[\mathrm{~m}]$ となったので $\epsilon=0.005[\mathrm{~m}]$ とした. 結果よりトルク制限にかからず目標軌 跡に追従しているのがわかる. 以上のシミュレーションおよ び実験結果より, 提案法がトルク制限内において作業精度と 最低速度条件を满足し, 輪郭制御性能の限界を達成している のがわかる。

\section{3 モデル化誤差に対するロバスト性の検証}

提案法のモデル化誤差に対するロバスト性を調べるため に, 真のモデルに対して修正要素 $F(s)$ が適切に設計されて いない場合における制御性能の影響について考察する。修正 要素 $F(s)$ の $K_{p}$ にモデル化誤差 $\Delta K_{p}$ を含んだ場合に $\Delta K_{p}$ が 制御性能に与える影響を考える. 真値と誤差の加わった值の 比率 $r_{p}=\left(K_{p}+\Delta K_{p}\right) / K_{p}$ を用いて, $\Delta K_{p}$ を変化させてど れだけ誤差が得られるか理論解析およびシミュレーションを 行った。

理論解析においては，数式モデルをもとに各軸における制 御性能として, 関節座標系でモー夕にランプ入力 $u(t)=v t$ を加え, 入力から誤差の加わったモデルの応答の遅れの解 析解

$$
\begin{aligned}
P(s) & =-\frac{\gamma\left(s+\left(K_{p}+\Delta K_{p}\right)\right)}{\left(K_{p}+\Delta K_{p}\right)(s-\gamma)} \frac{K_{p} K_{v}}{s^{2}+K_{v} s+K_{p} K_{v}} \frac{v}{s^{2}} \\
e & =v t-p(t)
\end{aligned}
$$

を求めた（18）式の理論解析に基づいて $r_{p}$ を変えたとき の誤差の様子を Fig. 8(a) に示す.

次に, この関節座標系における誤差を作業座標系において 評価する. シミュレーションで, $r_{p}$ を変えたときの目標軌跡 と追従軌跡の軌跡誤差を調べた. その結果を Fig. 8 に示す.

Fig. 8(a)(b) からもわかるように $r_{p}$ が極端に 1 からずれて も誤差は小さく, 現実的な数\%の $\Delta K_{p}$ の誤差では軌跡誤差は 無視できて, 本方法はモデル化誤差に対してロバスト性を有 している.

\section{6. まと め}

トルク制約条件下における産業用多関節ロボットアームの 
発生トルク, 作業精度と動作速度の 3 者の関係から, トルク 制約条件下で実現できる輪郭制御性能を明確にした。ささらに, この輪郭制御性能を実現するために, トルク制約内で指定し た作業精度を満たすように軌道を作業座標系で生成し，関節 座標系に教示信号修正法を適用する輪郭制御法を提案した。 また本方法の有用性を示すために仮想的トルク制限発生法を 多関節ロボットアーム装置 PERFORMER-MK3S に施して, シミュレーションおよび実験結果から本方法による優れた輪 郭制御性能を確認した。

本方法は, 産業用多関節ロボットの設計仕様から定まるト ルク制限がわかると，そのロボットが出しうる輪郭制御性能 の限界 (精度, 動作速度)がわかり, 逆に, 輪郭制御性能の仕 様が与えられば，実現に必要なトルク(パワーアンプ，モー タサイズ) を決定することができる。また，2 軸のロボット アームのみではなく，多軸のロボットアームにも適用でき， またロボットアームの入力を変更するのみでハード的な変更 を必要とせず，ロボットアームの有する最高制御性能を実現 できるため, 産業界の各種多関節ロボットアームの輪郭制御 において容易に採用することが可能である.

$$
\text { 参 考 文 献 }
$$

1) C.Burgat, S.Tarbouriech and M.Klai: Continuos-time saturated state feedback regulators: theory and design, Int. J. Systems Sci. .25-2, 315/335(1994).

2) C.W.Chan and K.Hui: Actuator saturation compensation for self-tuning controller, Int. J. Control, 59-2, $543 / 560(1994)$.

3）渡辺, 内田, 示村, 藤田: 制御入力が制限を受ける制御系に対 する Anti-Windup and Bumpless Transferの新しい設計法, 計測自動制御学会論文集, 30-6, 660/668(1994).

4) ビチャイ, 中野: 操作量の制約を考虑したタイムスケールを 用いた位置決め制御法式, 計測自動制御学会論文集, 30-7, $742 / 750(1994)$.

5) S.Goto, M.Nakamura and N.Kyura: A Modified Speed Data Method for Position Control of Mechanical Servo Systems, Trans. of the SICE, 30-6, 641/643(1994).

6) S.Goto, M.Nakamura and N.Kyura: Accurate Contour Control of Mechatronic Servo Systems Using Gaussian Networks, IEEE Transaction Industrial Electronics. 434, 469/476(1996).

7）後藤, 中村, 久良: メカトロサーボ系の高精度輪郭制御のため のガウシアンネットを用いた教示信号修正法, 電気学会論文誌 C, 115C-1, 111/116(1995).

8）竹内, 亀島, 浜田, 土屋: 知能情報を用いた動的軌道生成法, 日 本機会学会論文集 (C 編), 57-535, 167/171(1991).

9）後藤, 中村, 久良: ロボットアームの高速高精度位置決めの ための教示信号修正法, 計測自動制御学会論文集, 27-12, 1396/1404(1991).

10）久良修郭: ニューメカ講座, サーボ技術, 位置ループと速度 ループの関係, 日経メカニカル, 226-8, 135/140(1986).

11）中村, 香田, 久良: サーボ系に上る連続経路制御のサンプル值 制御に扔ける適正サンプル周波数の決定法, 計測自動制御学会 論文集, 28-5, 649/651(1992).

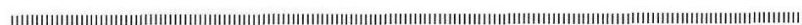

$$
\text { [著 者 紹介] }
$$

中 村 政 俊 (正会員)

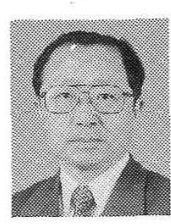

1943 年 8 月 20 日生. 73 年九州大学大学院工 学研究科電気工学専攻博士課程修了. 同年同大学 助手, 74 年佐賀大学講師, 75 年同助教授, 88 年 同教授, 98 年同大学院工学系研究科教授. 現在に 至る. 工学博士．システム制御の理論と応用の研 究に従事. 97 年計測自動制御学会フェロー, 電気 学会, 電子情報通信学会, システム制御情報学会, 日本ロボット学会, 日本脳波・筋電図学会, 日本 $M E$ 学会, IEEE 学会等の会員.

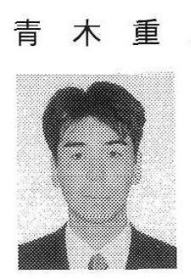

(学生会員)

1974 年 9 月 17 日生. 97 年佐賀大学理工学部電 気工学科卒業. 同年同大学院工学系研究科電気工 学専攻博士前期課程入学. 現在に至る. 主として メカニカルシステム制御の研究に従事.

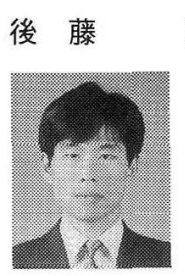

聡 (正会員)

1966 年 1 月 1 日生. 90 年大阪大学大学院工学 研究科応用物理学専攻博士前期課程修了. 同年佐 賀大学理工学部電気工学科助手, 96 年同講師, 98 年同大学院工学系研究科助教授. 現在に至る. 工 学博士. 主としてメカニカルシステム制御の研究 に従事. 電気学会, システム制御情報学会, 日本 ロボット学会等の会員.

\section{久良修郭 (正会員)}

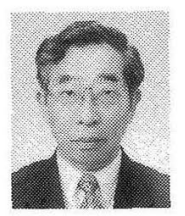

1942 年 2 月 12 日生. 66 年九州大学大学院工学 研究科電気工学専攻修士課程修了. 同年 (株) 安川 電機入社. 研究所, 技術開発センター, メカトロ 研究所所長を経て, 現在技術開発本部担当顧問, 95 年から近畿大学九州工学部教授併任. 工学博 士. 電気学会, 日本ロボット学会等の会員. 